\title{
Extinction of Remotely Acquired Fear Depends on an Inhibitory NR2B/PKA Pathway in the Retrosplenial Cortex
}

\author{
Kevin A. Corcoran, Katherine Leaderbrand, and Jelena Radulovic \\ Department of Psychiatry and Behavioral Sciences, The Asher Center for the Study and Treatment of Depressive Disorders, Feinberg School of Medicine, \\ Northwestern University, Chicago, Illinois 60611
}

As memories age, their processing increasingly relies upon cortical rather than hippocampal circuits, but the adaptive significance and mechanisms of this shift are not fully understood. Here we investigated the behavioral features and cortical mechanisms underlying extinction of remotely versus recently acquired context fear in mice. Behaviorally, extinction and reinstatement were similar, but reextinction of remote fear was significantly faster, suggesting time-dependent engagement of mechanisms specific for processing remote memory. Using pharmacological manipulations of NMDA receptors and associated signaling pathways in the in the retrosplenial cortex, we demonstrated that extinction of remote fear uniquely required NR2B-mediated downregulation of the cAMP-dependent protein kinase (PKA)/cAMP response element-binding protein pathway. Interestingly, NR2B/PKA interactions weakened independently of the age of the memory, but the functional significance of this molecular change was evident only as memory retrieval became PKA-dependent over time. Thus, cortical PKA signaling may provide a molecular signature of when a memory has become "remote," and inhibition of this pathway may open the door for modulation of remote memories.

\section{Introduction}

Memories undergo qualitative changes with the passage of time, becoming more schematic and semantic (Nadel et al., 2007), less detailed (Talamini and Gorree, 2012), and less vivid (Sheldon and Levine, 2013). Episodic/emotional components of memories are therefore more likely to decline as memories age, allowing for fear of adverse or even traumatic events to subside (St. St Jacques and Levine, 2007). These changes do not seem to occur in patients with post-traumatic stress disorder (PTSD), who continue to re-experience anxiety symptoms and fail to extinguish fear long after the stressful event (Yehuda et al., 1998). Although substantial advances have been made in our understanding of the formation and extinction of recently acquired fear (Myers and Davis, 2002; Tronson et al., 2012), the molecular and cellular mechanisms underlying extinction of remotely acquired fear are not known.

Extinction processes are tightly linked to memory retrieval (Ouyang and Thomas, 2005), which engages different neuroanatomical and neurobiological mechanisms as memory ages. Although retrieval initially requires both the hippocampus (Rudy et al., 2005) and cortex (Burwell et al., 2004; Corcoran et al., 2011),

\footnotetext{
Received Aug. 5, 2013; revised 0ct. 10, 2013; accepted Nov. 4, 2013.

Author contributions: K.A.C. and J.R. designed research; K.A.C. and K.L. performed research; K.A.C. and K.L. analyzed data; K.A.C. and J.R. wrote the paper.

This work was supported by National Institute of Mental Health Grants MH073669, MH078064, and Dunbar Funds to J.R. and K12GM088020 to K.A.C. We thank Michael Donnan, Katherine Cherry, and Franco Alarcon for technical assistance.

The authors declare no competing financial interests.

Correspondence should be addressed to either Kevin Corcoran or Jelena Radulovic, Department of Psychiatry and Behavioral Sciences, Feinberg School of Medicine, Northwestern University, 303 East Chicago Avenue, Ward 9-217, Chicago, IL 60611, E-mail: kevincorcoran@gmail.com or j-radulovic@northwestern.edu.

DOI:10.1523/JNEUROSCI.3338-13.2013

Copyright $\odot 2013$ the authors $\quad 0270-6474 / 13 / 3319492-07 \$ 15.00 / 0$
}

it eventually becomes more (Rudy et al., 2005; Lopez et al., 2012), or entirely (Squire et al., 2004; Frankland and Bontempi, 2005) dependent upon cortical networks. The time-dependent reorganization of memory retrieval is also reflected in region-specific changes of cellular activity (Tayler et al., 2013), dendritic spine growth (Lesburguères et al., 2011), and activation of immediate early genes (Bontempi et al., 1999; Frankland et al., 2004; Kwon et al., 2012). These molecular and cellular alterations relevant for memory retrieval may impact retrieval-dependent processes that also change over time, such as fear extinction (Inda et al., 2011).

To test this possibility, we performed a series of experiments aiming to characterize some of the molecular and behavioral features of extinction of remotely versus recently acquired context fear. Based on the time-independent involvement of retrosplenial cortex (RSC) NMDA receptors (NMDARs) in memory retrieval (Corcoran et al., 2011), we focused on NMDAR-dependent protein kinase signaling. We identified several key mechanisms specific for processing remote, but not recent memory: cAMP-dependent protein kinase (PKA) activity was selectively required for retrieval, whereas NR2B-mediated downregulation of PKA/cAMP response element-binding protein (CREB) signaling was required for fear extinction. This pathway may contribute to faster re-extinction after reinstatement of remote versus recent fear, thus providing a possible mechanism by which memory-induced fear responses decline over time.

\section{Materials and Methods}

Subjects. Nine-week-old male C57BL/6N mice were obtained from a commercial supplier (Harlan), individually housed on a $12 \mathrm{~h}$ light/dark cycle (lights on at 7 A.M.), and allowed ad libitum access to food and water. All procedures were approved by Northwestern University's Animal Care and Use Committee in compliance with National Institutes of Health standards. 
Surgery. Mice were anesthetized with avertin (1.2\%) and implanted with double 26 gauge guide cannulas (Plastics One) aimed at RSC (1.8 $\mathrm{mm}$ posterior, $\pm 0.4 \mathrm{~mm}$ lateral, $0.75 \mathrm{~mm}$ ventral to bregma). Mice were allowed at least $72 \mathrm{~h}$ to recover from surgery before behavioral procedures. After all behavioral procedures, verification of cannula placements was made from Nissl-stained coronal sections through RSC.

Drug infusions. Intra-RSC infusions were made using 28 gauge injectors that extended $1 \mathrm{~mm}$ beyond the end of the guide cannulas. All infusions were made at a rate of $0.64 \mu \mathrm{l} / \mathrm{min}$ for $15 \mathrm{~s}$, for a total volume of $0.16 \mu \mathrm{l} /$ side. Infusion cannulas were removed and dummy cannulas replaced immediately after the end of each drug infusion. Drug and vehicle (Veh) infusions were made immediately after the end of every extinction session, thus targeting the consolidation phase of extinction learning, but not within-session extinction. Pretest infusions were used only to identify mechanisms of memory retrieval, and were performed $30 \mathrm{~min}$ before placing mice in the conditioning chambers.

Drugs. We infused the following compounds in various experiments: the NR2A-preferring antagonist NVP-AAM007 $(1 \mu \mathrm{g} / \mu \mathrm{l}$ in aCSF; Novartis), NR2B-specific antagonist RO25-6981 $(2 \mu \mathrm{g} / \mu \mathrm{l}$ in $10 \%$ DMSO; Sigma-Aldrich), PKA inhibitor Rp-cAMPs $(36 \mu \mathrm{g} / \mu \mathrm{l}$ in aCSF; Sigma-Aldrich), PKA activator 8 -Br-cAMPs $(2.5 \mu \mathrm{g} / \mu \mathrm{l}$ in $0.9 \%$ saline; Sigma-Aldrich), AMPA receptor (AMPAR) antagonist CNQX (36 $\mu \mathrm{g} / \mu \mathrm{l}$ in 20\% DMSO; Sigma-Aldrich), dopamine D1 receptor antagonist SCH23390 $\left(2.5 \mu \mathrm{g} / \mu \mathrm{l}\right.$ in $40 \% \mathrm{aCSF} / \mathrm{H}_{2} \mathrm{O}$; Tocris Bioscience), norepinephrine $\beta$-receptor antagonist nadolol $(2 \mu \mathrm{g} / \mu \mathrm{l}$ in $40 \% \mathrm{aCSF} / \mathrm{H}_{2} \mathrm{O}$; Tocris Bioscience), and GABAa receptor agonist muscimol ( $1 \mu \mathrm{g} / \mu \mathrm{l}$; Sigma-Aldrich).

Behavioral apparatus. Fear conditioning and extinction training took place in Context A, a $35 \times 20 \times 20 \mathrm{~cm}$ clear Plexiglas chamber with a stainless steel rod floor ( $4 \mathrm{~mm}$ diameter, $0.9 \mathrm{~cm}$ center-to-center) situated in a sound-attenuating cabinet with black inner walls (TSE). After each mouse, this chamber was cleaned with a $70 \%$ ethanol solution. Context B comprised an equally sized tinted Plexiglas chamber with a similar grid floor. This chamber was situated in a white soundattenuating cabinet and cleaned with a $1 \%$ acetic acid solution.

Fear conditioning and extinction training. For fear conditioning, mice were placed in Context A and, 3 min later, presented with a footshock (2 $\mathrm{s}, 0.7 \mathrm{~mA}$, constant current). Extinction training began either $1 \mathrm{~d}$ (recent) or $35 \mathrm{~d}$ (remote) post-conditioning, and consisted of daily 3 min sessions in Context A without any shock presentations. In each experiment, extinction training continued until average freezing levels were significantly lower than during the first extinction session for at least three consecutive days; thus, all mice within an experiment received the same number of extinction sessions, but the number of extinction sessions differed across experiments.

Fear reinstatement and re-extinction training. One day after the last extinction session, mice were placed in the novel Context B and, $10 \mathrm{~s}$ later, presented with a footshock ( $2 \mathrm{~s} ; 1.0 \mathrm{~mA}$, constant current). Mice were returned to their home cages $5 \mathrm{~s}$ after this shock. The following day, reinstated freezing was scored during a 3 min test in Context A. This reminder shock procedure does not support fear conditioning to Context $\mathrm{B}$, but only results in reinstatement of fear in mice that were previously conditioned in Context A (Fischer et al., 2004). Subsequent to the reinstatement test, re-extinction consisted of six additional daily 3 min tests without shock.

Immunohistochemistry. For immunohistochemical analyses, mice were anesthetized with avertin $(1 \mathrm{ml}) 60 \mathrm{~min}$ after their final extinction session and transcardially perfused with cold $4 \%$ paraformaldehyde (PFA) in phosphate buffer. Brains were removed, postfixed in PFA for $48 \mathrm{~h}$, and then immersed in $10 \%, 20 \%$, and $30 \%$ sucrose in phosphate buffer for $24 \mathrm{~h}$ each. Coronal sections $(50 \mu \mathrm{m})$ were taken for freefloating immunohistochemistry with primary antibodies specific for NR2B (1:200, EMD; Millipore), pCREB (1:250; Cell Signaling Technology), and phospho-extracellular signal regulated protein kinase (pERK, 1:40,000; Sigma-Aldrich). Biotinylated secondary antibodies (1:200) and ABC complex (Vector Laboratories) were used for signal amplification, and 3,3'-diaminobenzidine (Sigma-Aldrich) served as the chromogen.

Coimmunoprecipitation and Western blotting. For coimmunoprecipitation analyses, RSC was collected $1 \mathrm{~h}$ after the final recent or remote extinction session or from naive mice. Tissue was immediately frozen in liquid nitrogen and then transferred to storage at $-80^{\circ} \mathrm{C}$ until lysis. ProteoExtract Subcellular Proteome Extraction Kit (Millipore) was used to generate membrane fractions that were subsequently used to study NR2B/PKA interactions.

Membrane fractions from two different mice of the same group were pooled to obtain $175 \mu \mathrm{g}$ per coimmunoprecipitation. Thus, from a total of six RSC/group we created three samples per group that were further analyzed. Immunoprecipitations were performed using Catch and Release Kit (Millipore) according to the user manual. NR2B-PKA complexes were isolated with $4 \mu \mathrm{g}$ NR2B antibody (Millipore) and $4 \mu \mathrm{g}$ mouse IgG (Sigma-Aldrich) was used as a negative control. Eluates and inputs were reduced in loading buffer with DTT and boiled for $5 \mathrm{~min}$ before electrophoresis. Samples were then subjected to SDS PAGE and transferred to polyvinylidene fluoride membranes (Millipore). Membranes were blocked with I-Block (Tropix), incubated with primary antibody overnight (PKA, catalytic subunit, 1:20,000; Abcam) at $4^{\circ} \mathrm{C}$ followed by corresponding secondary antibody (goat anti-rabbit 1:10,000; Santa Cruz Biotechnology) for $1 \mathrm{~h}$ at room temperature. Membranes were then incubated with alkaline phosphatase chemiluminescence enhancer (Nitro-Block II, Tropix) and substrate CDP Star (Tropix), and exposed to $\mathrm{x}$-ray film for detection.

Data collection and analysis. Fear responses were quantified by scoring freezing, defined as the absence of movement except that necessary for respiration, every $5 \mathrm{~s}$ by a trained observer blind to the experimental conditions, and expressed as the percentage of the total number of observations that the mice remained motionless.

For quantification of immunostaining, one coronal brain section, 1.8$1.95 \mathrm{~mm}$ posterior to bregma, was selected from each mouse. For cannulated mice, the section taken was just posterior to the cannula track, and was thus devoid of any cannula-related damage. These sections were selected because they showed the strongest PCREB staining and were in the vicinity of the drug injection site. Digital images were taken with a cooled color charge-coupled camera and SPOT software for Macintosh (Diagnostic Instruments). Image (NIH) was used for image processing. Cutoff thresholds were applied to each image to minimize background staining, and positively labeled cells were counted from within a 1.59 $\mathrm{mm} \times 0.37 \mathrm{~mm}$ rectangular region covering all of layer $2 / 3$ in each hemisphere of granular RSC. Cell counts were averaged across both hemispheres for each section.

Analyses of immunoblot data were performed by scanning the films and determining the band intensities densitometrically using ImageJ software.

Statistical differences were determined using ANOVA or Student's $t$ tests. Post hoc comparisons were made using Fisher-Hayter MLSD tests, and were considered significant for any $p<0.05$. Data are expressed as means \pm SEM.

\section{Results}

\section{Facilitated re-extinction after reinstatement of remote, but not recent, fear}

The design of this experiment is presented in Figure $1 A$. On day 0 , half of the mice (remote group, $n=8$ ) were fear conditioned in Context A. Thirty-four days later, the other half of the mice (recent group, $n=8$ ) were similarly fear conditioned. All mice subsequently underwent the following procedures on the same days, so that the only difference between the groups was the delay between fear conditioning and the beginning of extinction training on day 35 ( $1 \mathrm{~d}$ for the recent group, $35 \mathrm{~d}$ for the remote group). Extinction training consisted of nine daily 3 min tests in Context A without any shock presentation. During this initial extinction, there were no differences between the recent and remote groups in the rate of extinction or the extent to which freezing decreased $(F \leq 1.50 ; p>0.24$; Fig. $1 B)$.

Twenty-four hours after the last extinction session, mice received a reminder shock in Context B and, the following day, were tested for reinstatement of fear responses in Context A. 

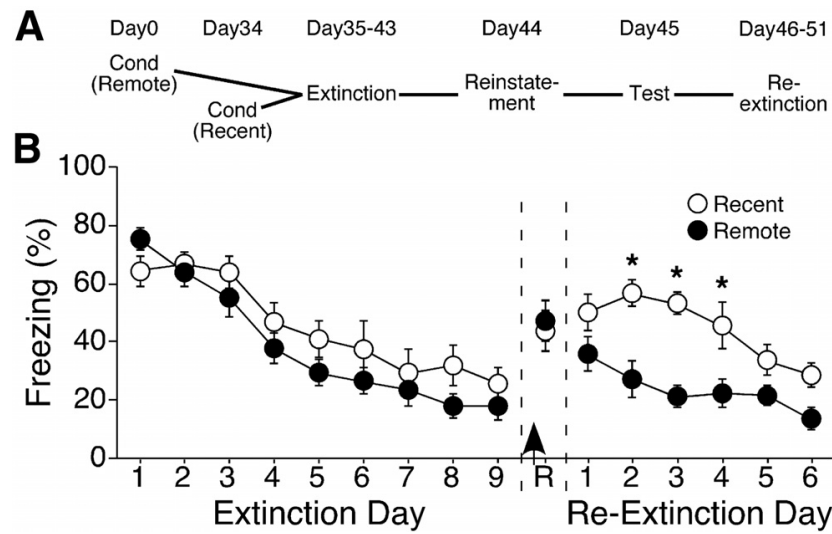

Figure 1. Facilitated re-extinction of remote context fear. $\boldsymbol{A}$, Design of the experiment in $\boldsymbol{B}$. Extinction of recent and remote context fear began $1 \mathrm{~d}$ (recent) or 35 days (remote) postconditioning. $\boldsymbol{B}$, Extinction of remote, but not recent, context fear is resistant to fear relapse. Mice in the recent and remote groups extinguished fear to the conditioning context at similar rates and to a similar extent. After receiving a strong footshock (arrow), both groups demonstrated similar levels of fear reinstatement (R). After reinstatement, however, re-extinction was facilitated in the remote group; ${ }^{*} p<0.01$.

Freezing levels were similar between the recent and remote groups $\left(t_{(14)}=0.12 ; p=0.73\right)$. Despite the lack of any differences during initial extinction or reinstatement testing, re-extinction was markedly different between the two groups. ANOVA revealed significant main effects of group $\left(F_{(1,14)}=14.64 ; p=\right.$ $0.002)$ and re-extinction day $\left(F_{(5,70)}=10.51 ; p<0.0001\right)$, as well as a group $\times$ re-extinction day interaction $\left(F_{(5,70)}=2.61 ; p=\right.$ 0.032 ). The persistence of low freezing levels in the remote group suggests that fundamental differences exist in the mechanisms underlying the extinction of recently versus remotely acquired memories.

\section{NR2B subunit-containing NMDAR are necessary for extinction of remote, but not recent, context fear}

We previously demonstrated that NR2A subunit-containing NMDAR in RSC are necessary for retrieval of both recently and remotely acquired context fear memories (Corcoran et al., 2011). To test whether NR2 subunits are similarly involved in fear extinction, we infused the NR2A-preferring and NR2B-specific antagonists NVP-AAM007 (NVP) and RO25-6981 (Ro) into RSC immediately after daily recent or remote extinction sessions (Fig. 2 ). Neither antagonist had any effect on the degree or rate of extinction for recently acquired fear (Ro, $n=8$; NVP, $n=8$; Veh, $n=7 ; F \leq 1.56$; $p>0.13$; Fig. $2 A$, left). In contrast, infusion of Ro, but not NVP, completely prevented extinction of remote fear (Fig. 2A, right). ANOVA revealed main effects of infusion (Ro, $n=9$; NVP, $n=8$; Veh, $\left.n=8 ; F_{(2,22)}=5.21 ; p=0.014\right)$ and extinction day $\left(F_{(5,100)}=34.97 ; p<0.0001\right)$, as well as an infusion $\times$ extinction day interaction $\left(F_{(10,100)}=5.51 ; p<0.0001\right)$. Post hoc analysis confirmed that mice in the Ro group froze more compared with the other two groups. This effect was specific to NR2 blockade, as infusion of the AMPA receptor antagonist CNQX had no effect on extinction of remote fear $\left(F_{(1,13)}=0.071\right.$; $p=0.79$; Fig. 2D).

The lack of effect of Ro on recent fear extinction could reflect the possibility that recent fear extinction is not dependent upon RSC-mediated processes. We therefore tested a role for RSC in recent extinction by infusing the GABAa receptor agonist muscimol (MUS) into RSC immediately after recent fear extinction sessions (Fig. 2C). ANOVA revealed significant main effects of

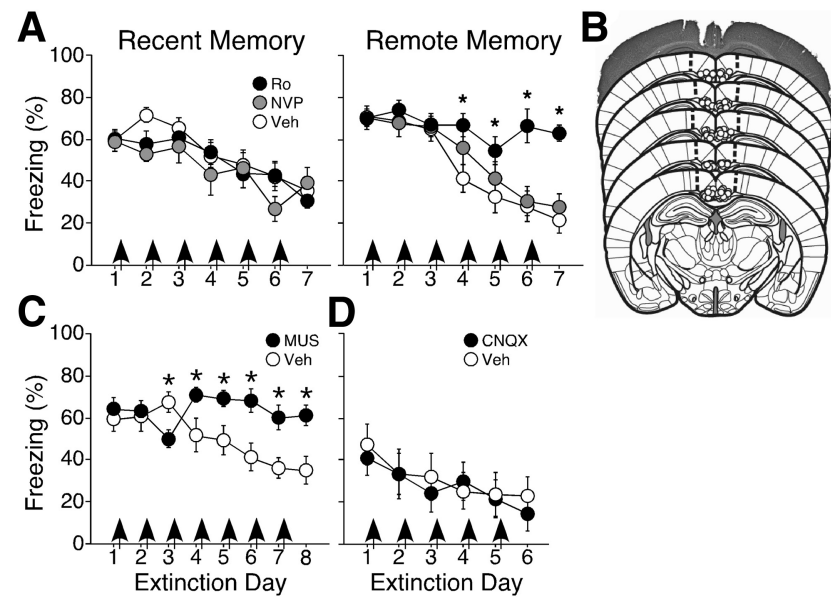

Figure 2. NR2B subunit-containing NMDAR in RSC mediate remote context fear extinction $A$, Extinction of recent context fear was unaffected by infusion of either the NR2A-preferring antagonist NVP or NR2B-specific antagonist Ro (left). In contrast, Ro, but not NVP, blocked extinction of remote fear (right). $\boldsymbol{B}$, Cannula placements in RSC. The photomicrograph shows a cresyl violet-stained coronal section with representative bilateral cannula placements in RSC. Illustrated below that are the locations of individual cannula placements. Atlas templates adapted from Paxinos and Franklin (2001). C, Recent fear extinction was prevented by inactivation of RSC via the GABAa receptor agonist MUS. D, Extinction of remotely acquired fear was unaffected by infusion of the AMPAR antagonist CNQX. All arrows indicate post-extinction infusions; ${ }^{*} p<0.05$ from the Veh group.
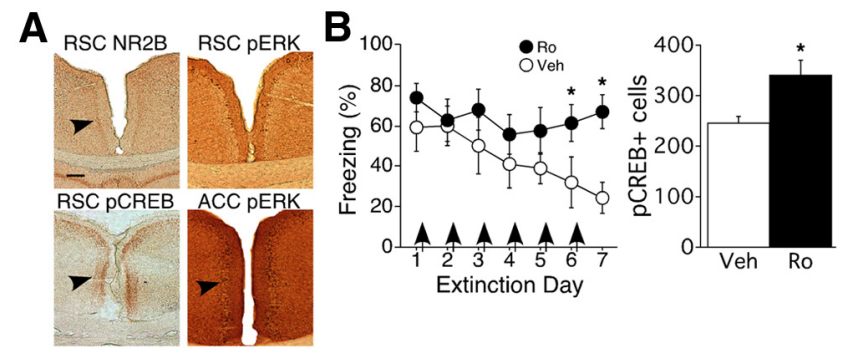

Figure 3. NR2B blockade during remote extinction leads to increased pCREB. $A, A f t e r 3 \mathrm{~d}$ of extinction training, we found robust immunostaining for NR2B and pCREB, but not pERK, in RSC. pERK was highly expressed in ACC in the same brain. Arrowheads point to regions of dense immunostaining. Scale bar, $250 \mu \mathrm{m}$. $B$, Consistent with our previous results, infusion of Ro into RSC blocked remote fear extinction. Ro also led to an increase in $\mathrm{PCREB}+$ cells relative to vehicle controls. Arrows indicate post-extinction infusions; ${ }^{*} p<0.05$.

infusion (MUS, $n=8$; Veh, $n=8 ; F_{(1,14)}=4.66$; $p<0.05$ ) and extinction day $\left(F_{(6,84)}=5.71 ; p<0.0001\right)$, and a significant infusion $\times$ extinction day interaction $\left(F_{(6,84)}=10.88 ; p<\right.$ $0.0001)$. Post hoc tests confirmed that mice in the MUS group froze more than mice in the Veh group. Thus, RSC is necessary for the extinction of both recently and remotely acquired context fear memories, but only extinction of remote context fear is specifically dependent upon activation of NR2B subunit-containing NMDAR.

\section{NR2B inhibits the PKA/CREB signaling pathway during remote extinction}

Brain sections were taken from mice after $3 \mathrm{~d}$ of remote extinction training and stained for levels of pCREB and pERK in RSC and anterior cingulate cortex (ACC; Fig. 3A). We chose to examine sections taken at this time because in hippocampus, molecular mechanisms necessary for contextual fear extinction are most strongly activated after 3-4 d of extinction training, shortly before significant reductions in freezing are observed (Fischer et al., 


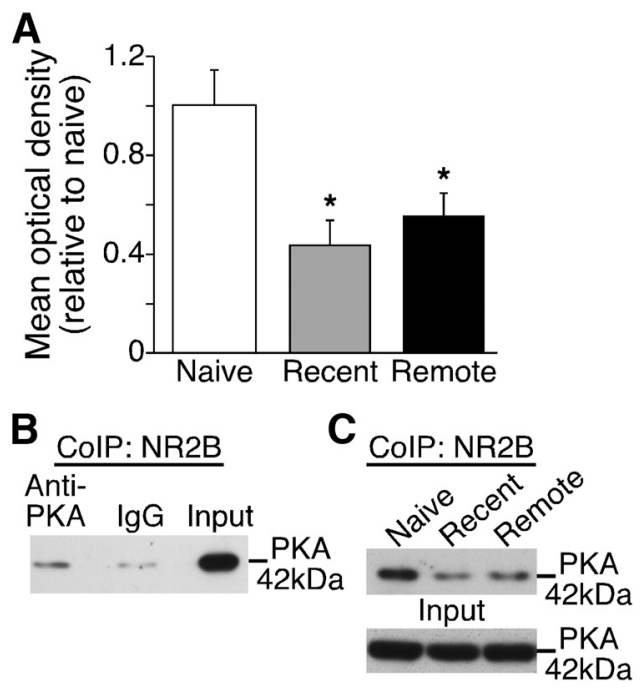

Figure 4. NR2B/PKA interactions in RSC are reduced after both recent and remote fear extinction. $A$, Coimmunoprecipitation of NR2B and PKA revealed decreased NR2B/ PKA complexes after recent and remote extinction; ${ }^{*} p<0.01$. $\boldsymbol{B}$, Validation of the coimmunoprecipitation approach, demonstrating a strong PKA band after incubation of membrane lysates with NR2B antibody but not lgG. C, Representative immunoblots showing significant reductions in NR2B/PKA complexes after recent and remote fear extinction.

2007). We focused on the CREB and ERK signaling pathways because their activity in other brain regions has previously been shown to be necessary for fear extinction (Fischer et al., 2007; Izumi et al., 2008; Tronson et al., 2008, 2009, 2012). We included ACC for comparison because it contributes to the retrieval of remote context fear (Frankland et al., 2004), but unlike RSC, it does so through non-NMDAR-dependent mechanisms (Corcoran et al., 2011). We consistently observed robust expression of pCREB in layer $2 / 3$ of RSC, which also contains high levels of NR2B. Surprisingly, only a few scattered pERK-positive cells were seen in RSC. This was not due to an immunodetection problem given that pERK was highly upregulated in both cell bodies and fibers in ACC of the same brains.

Because PCREB was robustly expressed in the same layer of RSC as NR2B, we next examined the effect of NR2B antagonism on extinction-related CREB phosphorylation. Consistent with our previous findings, post-extinction infusion of Ro prevented remote fear extinction; ANOVA revealed a main effect of extinction day (Ro, $n=6$; Veh, $n=4 ; F_{(5,40)}=4.30 ; p=0.003$ ) and a significant infusion $\times$ extinction day interaction $\left(F_{(5,40)}=4.31\right.$; $p=0.003$; Fig. 3B, left). Post hoc tests confirmed that mice in the Ro group froze more than mice in the Veh group. In addition, RSC pCREB levels were elevated in the Ro group $\left(t_{(8)}=6.60 ; p=\right.$ 0.033 ; Fig. $3 B$, right). These results point to a signaling pathway for remote fear extinction in which NR2B activity reduces phosphorylation of CREB, leading to the cessation of freezing responses.

A likely link between NR2B activity and CREB phosphorylation is PKA, a kinase that both regulates and is regulated by NMDAR. We therefore examined whether the inhibitory effect of NR2B involves alterations of NR2B/PKA complexes. Coimmunoprecipitation yielded a significant reduction of NR2B/PKA interactions after extinction $\left(F_{(2,8)}=17.08, p=0.003\right.$; Fig. $\left.4 A\right)$. Surprisingly, this effect was independent of memory age, as it was observed after extinction of both recently $(p=0.005)$ and remotely $(p=0.010)$ acquired fear. Thus, unlike the time-
A
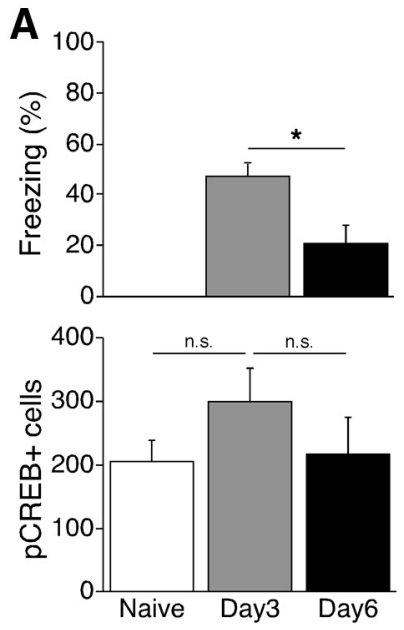

B
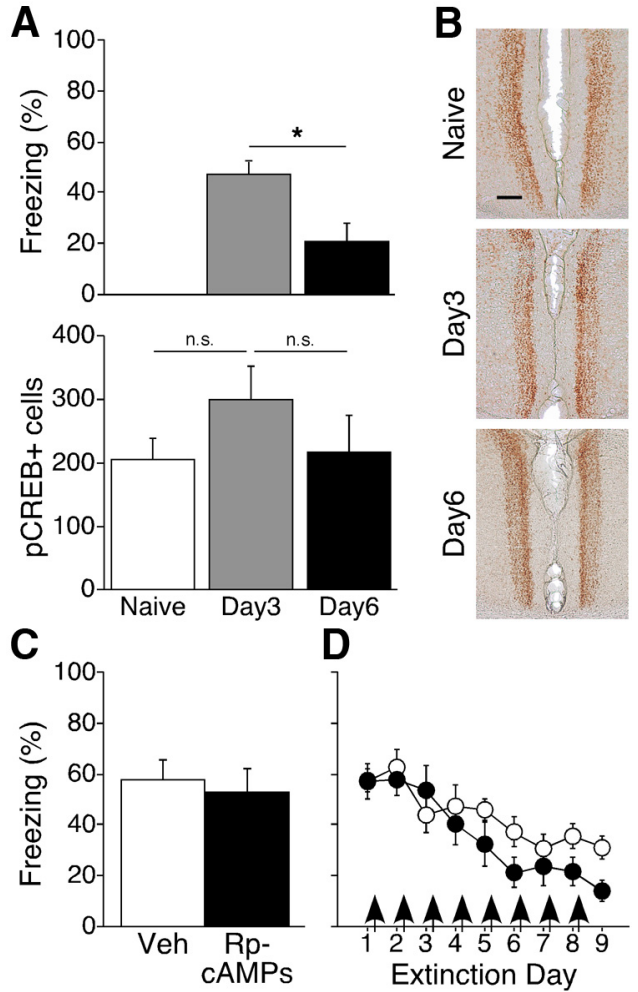

D

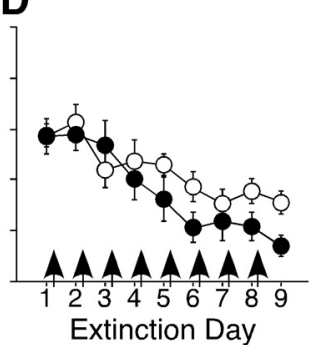

Figure 5. Retrieval and extinction of recently acquired fear do not require changes in $p C R E B$ or PKA-dependent signaling. A, Top, Freezing levels during the final extinction session for each group. Bottom, Although freezing levels were much lower for the day 6 group, the number of $\mathrm{pCREB}+$ cells was similar among naive, day 3 , and day 6 groups; ${ }^{*} p<0.01$. B, Representative sections showing immunostaining of pCREB + cells in layer 2/3 of RSC. Scale bar, $125 \mu \mathrm{m}$. C, Inhibition of PKA via Rp-CAMPs had no effect on retrieval of recent fear memory. $D$, PKA inhibition had no effect on extinction of recently acquired fear. Arrows indicate post-extinction infusions.

dependent role of NR2B in remote extinction, inhibition of the RSC PKA/CREB signaling pathway may be required for both recent and remote fear extinction.

PKA/pCREB activation in RSC is associated with remote fear retrieval and is reversed by extinction training

To test the role of PKA/pCREB signaling in recent and remote extinction, we first measured pCREB + cells in RSC in naive mice, and in mice that received 3 or $6 \mathrm{~d}$ of recent extinction training, representing times at which mice expressed high and low levels of freezing, respectively (naïve, $n=6$; day $3, n=6$; day $6, n=6 ; t_{(10)}=10.43 ; p=$ 0.0090; Fig. $5 A$, top). Relative to levels in naive mice, however, there were no differences in $\mathrm{PCREB}+$ cells at any time $\left(F_{(2,15)}=1.15 ; p=\right.$ 0.34 ; Fig. $5 A$, bottom). Consistent with the lack of changes in pCREB levels after recent retrieval and extinction, pretest infusion of the PKA inhibitor Rp-cAMPs had no effect on recent context memory retrieval (Rp-cAMPs, $n=8$; Veh, $n=8 ; t_{(14)}=0.41 ; p=0.69$; Fig. $5 C$ ), and post-extinction infusions of Rp-cAMPs had no effect on either the rate or degree of recent fear extinction (Rp-cAMPs, $n=8$; Veh, $n=7 ; F \leq 1.45 ; p>0.19$; Fig. $5 D$ ).

A similar decrease in freezing was seen between 3 and $6 \mathrm{~d}$ of remote extinction training (naïve, $n=6$; day $3, n=6$; day $6, n=$ $5 ; t_{(9)}=43.57 ; p<0.0001$; Fig. $6 A$, top), which was accompanied by significant changes in $\mathrm{pCREB}+$ cells $\left(F_{(2,14)}=4.86 ; p=0.025\right.$; Fig. 6A, bottom). Post hoc tests confirmed an increase in pCREB + cells over naive levels after $3 \mathrm{~d}$ of extinction training, and a significant decrease from 3 to $6 \mathrm{~d}$, as the number of 

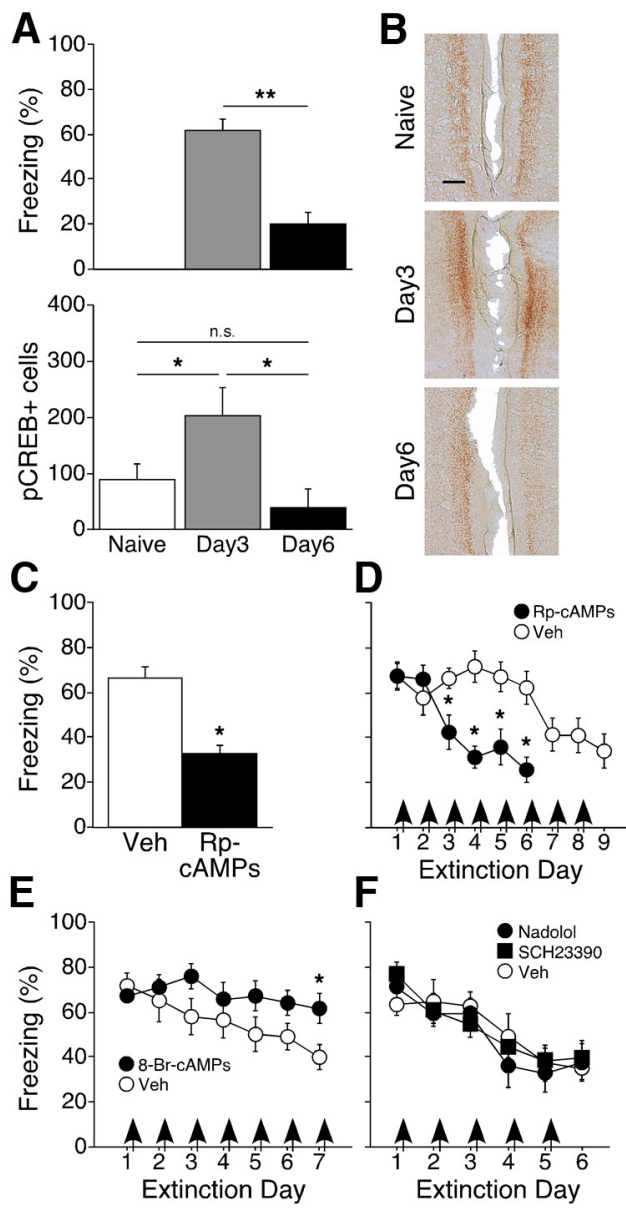

Figure 6. Retrieval and extinction of remotely acquired fear are mediated by increased and decreased PKA activity and CREB phosphorylation, respectively. $A$, Top, Freezing levels during the final extinction session for each group. Bottom, the number of pCREB + cells in RSC was increased relative to naive mice after $3 d$, and returned to baseline levels after $6 d$, of extinction training, mirroring the differences in freezing between the day 3 and day 6 groups. $\boldsymbol{B}$, Representative sections showing immunostaining of pCREB + cells in layer $2 / 3$ of RSC. Scale bar, 125 $\mu \mathrm{m}$. C, Inhibition of PKA via Rp-CAMPS blocked retrieval of remote fear memory. $\boldsymbol{D}$, Inhibition of PKA facilitated extinction of remotely acquired fear. $\boldsymbol{E}$, Activation of PKA via 8-Br-cAMPs blocked remote extinction. $\boldsymbol{F}$, Remote extinction was unaffected by infusions of the $\beta$-receptor antagonist nadolol or the D1 receptor antagonist SCH23390. Arrows indicate post-extinction infusions; ${ }^{*} p<0.05$.

pCREB + cells returned to naive levels. Thus, fluctuations of pCREB levels in RSC were significant only during processing of remote memory, increasing with retrieval and decreasing with extinction. These findings predicted that PKA blockade would selectively effect remote retrieval and extinction.

Consistent with this, pretest infusion of Rp-cAMPs significantly reduced freezing during remote memory testing (RpcAMPs, $n=7$; Veh, $n=16$; $t_{(21)}=4.68$; $p<0.0001$; Fig. $\left.6 C\right)$. Moreover, post-extinction infusions of Rp-cAMPs greatly facilitated the extinction of remote fear (Fig. 6D). ANOVA revealed significant main effects of infusion (Rp-cAMPs, $n=8$; Veh, $n=$ $\left.7 ; F_{(1,13)}=7.54 ; p=0.017\right)$ and extinction day $\left(F_{(5,65)}=8.41 ; p<\right.$ $0.0001)$, and a significant infusion $\times$ extinction day interaction $\left(F_{(5,65)}=12.27 ; p<0.0001\right)$ during the first $6 \mathrm{~d}$ of extinction training. Post hoc tests confirmed that the Rp-cAMPs group froze significantly less than the Veh group. An additional $3 \mathrm{~d}$ of extinction training resulted in freezing levels in the Veh group that were similar to that of the Rp-cAMPs group after $6 \mathrm{~d}$, demonstrating that the ability to inhibit freezing responses was not impaired in these mice. Collectively, these results suggest that, with the passage of time, retrieval and extinction of context fear shift from PKA-independent to PKA-dependent mechanisms.

We confirmed the role of PKA in remote extinction via postextinction infusions of the CAMP analog and PKA activator 8-BrcAMPs (Fig. 6E). ANOVA revealed a significant main effect of extinction day (8-Br-cAMPs, $n=8$; Veh, $n=7 ; F_{(6,78)}=6.87$; $p<0.0001)$ and a significant infusion $\times$ extinction day interaction $\left(F_{(6,78)}=2.88 ; p=0.014\right)$. Post hoc tests confirmed that mice in the 8-Br-cAMPs group froze more than mice in the Veh group. Activation of either norepinephrine $\beta$-receptors (Neve et al., 2004) or dopamine D1 receptors (Hall, 2004) also increases PKA activity, suggesting that deactivation of these receptors in RSC could contribute to remote fear extinction. To test this, we infused antagonists of either $\beta$-receptors (nadolol) or D1 receptors (SCH23390) immediately after daily extinction sessions (Fig. $6 F$ ). Neither antagonist had any effect on the rate or magnitude of remote fear extinction (nadolol, $n=8$; SCH23390, $n=8$; Veh, $n=7 ; F \leq 1.32 ; p>0.22$ ), suggesting that the decrease in PKA activity necessary for remote extinction is predominantly mediated by activation of NR2B.

\section{Discussion}

We demonstrated that extinction of recently and remotely acquired fear initially followed a similar time course, however, after reinstatement, re-extinction of remote fear was facilitated. Although a within-subjects design may have been more advantageous for detecting differences in extinction-related phenomena that depend on memory age, as has been previously observed for spontaneous recovery of conditioned reward (Rescorla, 2004), we could not implement such a design here because molecular analyses would have been confounded by exposure to multiple contexts. Given that retrieval of recent and remote fearprovoking context memories does not vary depending on whether a within- or between-subjects design is used (Kim and Fanselow, 1992; Anagnostaras et al., 1999; Corcoran et al., 2011), and because we found similar extinction and reinstatement behavior in both recent and remote groups, the age of the memory, rather than the experimental design, caused the faster reextinction in remotely conditioned mice.

This facilitation may reflect the fact that remote fear extinction uniquely depended on a signaling cascade in RSC involving NR2B activation, untethering of NR2B/PKA complexes, reduced PKA activation, and diminished CREB phosphorylation. Consistent with this mechanism, inhibition and activation of PKA significantly accelerated and impaired extinction of remote context fear, respectively. Reduced NR2B/PKA interactions found after both recent and remote extinction were irrelevant for recent extinction, but gained significance as memory aged and its retrieval became PKA-dependent. Extinction was unaffected by antagonism of NR2A receptors, which mediate RSC-dependent fear memory retrieval (Corcoran et al., 2011), or by blocking PKA signaling via $\beta$-adrenergic and D1 receptors. These findings reveal distinct mechanisms in RSC for processing remote versus recent memory, centered on an inhibitory NR2B/PKA pathway that gains significance as memory ages.

Information acquired during initial learning profoundly impacts subsequent learning (Escobar et al., 2002; Matus-Amat et al., 2004), and thus we propose that engagement of the NR2B/ $\mathrm{PKA} / \mathrm{pCREB}$ pathway during remote extinction sets the stage for rapid re-extinction. Nevertheless, mechanisms of extinction and re-extinction differ at molecular and circuit levels (Laurent and Westbrook, 2008, 2010; Laurent et al., 2008), raising the possibil- 
ity that faster remote re-extinction is mediated by independent mechanisms. Unfortunately, these possibilities were difficult to tease apart in our experiments, because manipulations that alter initial extinction preclude the ability to test reinstatement and re-extinction. For example, reinstatement could not be performed after NR2B antagonism because freezing never subsided. Similarly, remote re-extinction was so rapid that further enhancement would have been difficult to detect. Additional studies are warranted to establish the extent to which the processes mediating initial extinction impact re-extinction.

The necessity of RSC NR2B in fear extinction was not surprising, given ample evidence of a role for this receptor in key regions of the fear circuit, including the hippocampus (Tang et al., 1999), amygdala (Sotres-Bayon et al., 2007; Laurent et al., 2008), and prefrontal cortex (Sotres-Bayon et al., 2009), in extinction of recently acquired context or cue-dependent fear. RSC NR2B are unique, however, in that they are specifically involved in remote, but not recent, fear extinction. This pattern is similar for downregulation of PKA, which in hippocampus is required for extinction of recently acquired context fear (Nijholt et al., 2008), but in RSC is specific for remote fear extinction. Thus, in transgenic mice that express a dominant-negative form of PKA, the enhancement of context fear extinction found both shortly and long after fear conditioning (Isiegas et al., 2006) likely involves different brain areas as the memory ages. Together, these findings suggest that mechanisms underlying remote and recent fear extinction are similar, but occur in different brain regions. However, this generalization is inconsistent with the observation that upregulation of limbic/prefrontal ERK activity, which is critical for recent fear extinction (Fischer et al., 2007; Ryu et al., 2008; Tronson et al., 2009; Matsuda et al., 2010), is absent in the RSC. This opens the possibility that extinction of remotely versus recently acquired fear is more effective because it relies upon a more limited set of cortical signaling pathways.

The effects of NR2B on PKA signaling differ depending on regional, cellular, and subcellular contexts. For example, PKA/pCREB signaling is enhanced by NR2B in ACC in rodent models of pain (Cao et al., 2012), in hippocampus as a result of genetic NR2B overexpression ( $\mathrm{Li}$ et al., 2011), and in piriform cortex in response to olfactory activity (Kim et al., 2006). In contrast, multiple findings, including ours, point to the presence of inhibitory NR2B/PKA interactions. Coapplication of NMDA with an NR2B antagonist enhances PKA signaling and LTP (Oh-Nishi et al., 2009), as does activation of extrasynaptic NMDAR (Hardingham et al., 2002). Similarly, NMDA treatments that induce LTD lead to removal of PKA regulatory subunit II from membrane NMDAR complexes, which results in decreased PKA activity (Smith et al., 2006). In our study, this inhibitory mechanism was manifest in decreased interactions between NR2B and PKA after extinction, and increased pCREB-immunoreactivity after NR2B antagonism.

The selective engagement of inhibitory NR2B/PKA interactions in remote extinction suggests that this mechanism of fear extinction develops with time. Our analysis of NR2B and PKA interactions and PCREB after recent and remote memory, however, hints at an alternative possibility. Early decreases of RSC NR2B/PKA interactions may reflect tagging of cortical networks that occurs shortly after learning, but gains significance only after the memory has aged (Lesburguères et al., 2011). In keeping with this, only remote memory retrieval was prevented by PKA inhibition, and the behavioral effects of NR2B and PKA antagonism, as well as decreased CREB phosphorylation, were only seen during remote fear extinction. The later recruitment of RSC PKA in memory processing may therefore provide a molecular signature for when a memory has become "remote". A key question for future studies is identification of the molecular mechanisms underlying this delayed cortical PKA recruitment.

In summary, mechanisms of remote versus recent fear extinction yield a reduction in fear responses that is much more resilient in the face of subsequent stressors. The endurance of PTSD symptoms, such as retrieval of trauma-related memories and vivid flashbacks to remote traumatic events (Solomon et al., 2009), are thought to reflect impaired extinction (Rothbaum and Davis, 2003). Our study suggests an additional possibility: that memory fails to age and relies upon the less effective mechanisms of recent extinction. Optimal treatment for PTSD may therefore need to be tailored to the "neuronal age" of the trauma memory and target the appropriate neurobiological mechanism.

\section{References}

Anagnostaras SG, Maren S, Fanselow MS (1999) Temporally graded retrograde amnesia of contextual fear after hippocampal damage in rats: within-subjects examination. J Neurosci 19:1106-1114. Medline

Bontempi B, Laurent-Demir C, Destrade C, Jaffard R (1999) Timedependent reorganization of brain circuitry underlying long-term memory storage. Nature 400:671-675. CrossRef Medline

Burwell RD, Bucci DJ, Sanborn MR, Jutras MJ (2004) Perirhinal and postrhinal contributions to remote memory for context. J Neurosci 24 : 11023-11028. CrossRef Medline

Cao H, Ren WH, Zhu MY, Zhao ZQ, Zhang YQ (2012) Activation of glycine site and GluN2B subunit of NMDA receptors is necessary for ERK/CREB signaling cascade in rostral anterior cingulated cortex in rats: implications for affective pain. Neurosci Bull 28:77-87. CrossRef Medline

Corcoran KA, Donnan MD, Tronson NC, Guzmán YF, Gao C, Jovasevic V, Guedea AL, Radulovic J (2011) NMDA receptors in retrosplenial cortex are necessary for retrieval of recent and remote context fear memory. J Neurosci 31:11655-11659. CrossRef Medline

Escobar M, Arcediano F, Miller RR (2002) Latent inhibition and contextual associations. J Exp Psychol Anim Behav Process 28:123-136. CrossRef Medline

Fischer A, Sananbenesi F, Schrick C, Spiess J, Radulovic J (2004) Distinct roles of hippocampal de novo protein synthesis and actin rearrangement in extinction of contextual fear. J Neurosci 24:1962-1966. CrossRef Medline

Fischer A, Radulovic M, Schrick C, Sananbenesi F, Godovac-Zimmermann J, Radulovic J (2007) Hippocampal Mek/Erk signaling mediates extinction of contextual freezing behavior. Neurobiol Learn Mem 87:149-158. CrossRef Medline

Frankland PW, Bontempi B (2005) The organization of recent and remote memories. Nat Rev Neurosci 6:119-130. CrossRef Medline

Frankland PW, Bontempi B, Talton LE, Kaczmarek L, Silva AJ (2004) The involvement of the anterior cingulate cortex in remote contextual fear memory. Science 304:881-883. CrossRef Medline

Hall RA (2004) $\beta$-Adrenergic receptors and their interacting proteins. Semin Cell Dev Biol 15:281-288. CrossRef Medline

Hardingham GE, Fukunaga Y, Bading H (2002) Extrasnaptic NMDARs oppose synaptic NMDARs by triggering CREB shut-off and cell death pathways. Nat Neurosci 5:405-414. Medline

Inda MC, Muravieva EV, Alberini CM (2011) Memory retrieval and the passage of time: from reconsolidation and strengthening to extinction. J Neurosci 31:1635-1643. CrossRef Medline

Isiegas C, Park A, Kandel ER, Abel T, Lattal KM (2006) Transgenic inhibition of neuronal protein kinase A activity facilitates fear extinction. J Neurosci 26:12700-12707. CrossRef Medline

Izumi T, Inoue T, Kato A, Kitaichi Y, Nakagawa S, Koyama T (2008) Changes in amygdala neural activity that occur with the extinction of context-dependent conditioned fear stress. Pharmacol Biochem Behav 90:297-304. CrossRef Medline

Kim HH, Puche AC, Margolis FL (2006) Odorant deprivation reversibly modulates transsynaptic changes in the N2B-mediated CREB shut-off and cell death pathways. J Neurosci 26:9548-9559. CrossRef Medline

Kim JJ, Fanselow MS (1992) Modality-specific retrograde amnesia of fear. Science 256:675-677. CrossRef Medline

Kwon JT, Jhang J, Kim HS, Lee S, Han JH (2012) Brain region-specific 
activity patterns after recent or remote memory retrieval of auditory conditioned fear. Learn Mem 19:487-494. CrossRef Medline

Laurent V, Westbrook RF (2008) Distinct contributions of the basolateral amygdala and the medial prefrontal cortex to learning and relearning extinction of context conditioned fear. Learn Mem 15:657-666. CrossRef Medline

Laurent V, Westbrook RF (2010) Role of the basolateral amygdala in the reinstatement and extinction of fear responses to a previously extinguished conditioned stimulus. Learn Mem 17:86-96. CrossRef Medline

Laurent V, Marchand AR, Westbrook RF (2008) The basolateral amygdala is necessary for learning but not relearning extinction of context conditioned fear. Learn Mem 15:304-314. CrossRef Medline

Lesburguères E, Gobbo OL, Alaux-Cantin S, Hambucken A, Trifilieff P, Bontempi B (2011) Early tagging on cortical networks is required for the formation of enduring associative memory. Science 331:924-928. CrossRef Medline

Li C, Dong S, Wang H, Hu Y (2011) Microarray analysis of gene expression changes in the brains of NR2B-induced memory-enhanced mice. Neuroscience 197:121-131. CrossRef Medline

Lopez J, Herbeaux K, Cosquer B, Engeln M, Muller C, Lazarus C, Kelche C, Bontempi B, Cassel JC, de Vasconselos AP (2012) Context-dependent modulation of hippocampal and cortical recruitment during remote spatial memory retrieval. Hippocampus 22:827-841. CrossRef Medline

Matsuda S, Matsuzawa D, Nakazawa K, Sutoh C, Ohtsuka H, Ishii D, Tomizawa H, Iyo M, Shimizu E (2010) d-Serine enhances extinction of auditory cued fear conditioning via ERK1/2 phosphorylation in mice. Prog Neuropsychopharmacol Biol Psychiatry 34:895-902. CrossRef Medline

Matus-Amat P, Higgins EA, Barrientos RM, Rudy JW (2004) The role of the dorsal hippocampus in the acquisition and retrieval of context memory representations. J Neurosci 24:2431-2439. CrossRef Medline

Myers KM, Davis M (2002) Behavioral and neural analysis of extinction. Neuron 36:567-584. CrossRef Medline

Nadel L, Campbell J, Ryan L (2007) Autobiographical memory retrieval and hippocampal activation as a function of repetition and the passage of time. Neural Plast 2007:90472. CrossRef Medline

Neve KA, Seamans JK, Trantham-Davidson H (2004) Dopamine receptor signaling. J Recept Signal Transduct Res 24:165-205. CrossRef Medline

Nijholt IM, Ostroveanu A, Scheper WA, Penke B, Luiten PG, Van der Zee EA, Eisel UL (2008) Inhibition of PKA anchoring to A-kinase anchoring proteins impairs consolidation and facilitates extinction of contextual fear memories. Neurobiol Learn Mem 90:223-229. CrossRef Medline

Oh-Nishi A, Saji M, Satoh SZ, Ogata M, Suzuki N (2009) Late pase of longterm potentiation induced by co-application of $\mathrm{N}$-methyl-d-aspartic acid and the antagonist of NR2B-containing $N$-methyl-D-aspartic acid receptors in rat hippocampus. Neuroscience 159:127-135. CrossRef Medline

Ouyang M, Thomas SA (2005) A requirement for memory retrieval during and after long-term extinction learning. Proc Natl Acad Sci U S A 102: 9347-9352. CrossRef Medline

Paxinos G, Franklin KBJ (2001) The mouse brain in stereotaxic coordinates. San Diego: Academic.

Rescorla RA (2004) Spontaneous recovery varies inversely with the training-extinction interval. Learn Behav 32:401-408. CrossRef Medline

Rothbaum BO, Davis M (2003) Applying learning principles to the treat- ment of post-trauma reactions. Ann NY Acad Sci 1008:112-121. CrossRef Medline

Rudy JW, Biedenkapp JC, O'Reilly RC (2005) Prefrontal cortex and the organization of recent and remote memories: an alternative view. Learn Mem 12:445-446. CrossRef Medline

Ryu J, Futai K, Feliu M, Weinberg R, Sheng M (2008) Constitutively active Rap2 transgenic mice display fewer dendritic spines, reduced extracellular signal-regulated kinase signaling, enhanced long-term depression, and impaired spatial learning and fear extinction. J Neurosci 28:8178-8188. CrossRef Medline

Sheldon S, Levine B (2013) Same as it ever was: vividness modulates the similarities and differences between the neural networks that support retrieving remote and recent autobiographical memories. Neuroimage 83:880-891. CrossRef Medline

Smith KE, Gibson ED, Dell'Acqua ML (2006) cAMP-dependent protein kinase postsynaptic localization regulated by NMDA receptor activation through translocation of an A-kinase anchoring protein scaffold protein. J Neurosci 26:2391-2402. CrossRef Medline

Solomon Z, Horesh D, Ein-Dor T (2009) The longitudinal course of posttraumatic stress disorder symptom clusters among war veterans. J Clin Psychiatry 70:837-843. CrossRef Medline

Sotres-Bayon F, Bush DE, LeDoux JE (2007) Acquisition of fear extinction requires activation of NR2B-containing NMDA receptors in the lateral amygdala. Neuropsychopharmacology 32:1929-1940. CrossRef Medline

Sotres-Bayon F, Diaz-Mataix L, Bush DE, LeDoux JE (2009) Dissociable roles for the ventromedial prefrontal cortex and amygdala in fear extinction: NR2B contribution. Cereb Cortex 19:474-482. CrossRef Medline

Squire LR, Stark CE, Clark RE (2004) The medial temporal lobe. Annu Rev Neurosci 27:279-306. CrossRef Medline

St Jacques PL, Levine B (2007) Ageing and autobiographical memory for emotional and neutral events. Memory 15:129-144. CrossRef Medline

Talamini LM, Gorree E (2012) Aging memories: differential decay of episodic memory components. Learn Mem 19:239-246. CrossRef Medline

Tang YP, Shimizu E, Dube GR, Rampon C, Kerchner GA, Zhuo M, Liu G, Tsien JZ (1999) Genetic enhancement of learning and memory in mice. Nature 401:63-69. CrossRef Medline

Tayler KK, Tanaka KZ, Reijmers LG, Wiltgen BJ (2013) Reactivation of neural ensembles during the retrieval of recent and remote memory. Curr Biol 23:99-106. CrossRef Medline

Tronson NC, Schrick C, Fischer A, Sananbenesi F, Pagès G, Pouysségur J, Radulovic J (2008) Regulatory mechanisms of fear extinction and depression-like behavior. Neuropsychopharmacology 33:1570-1583. CrossRef Medline

Tronson NC, Schrick C, Guzman YF, Huh KH, Srivastava DP, Penzes P, Guedea AL, Gao C, Radulovic J (2009) Segregated populations of hippocampal principal CA1 neurons mediating conditioning and extinction of contextual fear. J Neurosci 29:3387-3394. CrossRef Medline

Tronson NC, Corcoran KA, Jovasevic V, Radulovic J (2012) Fear conditioning and extinction: emotional states encoded by distinct signaling pathways. Trends Neurosci 35:145-155. CrossRef Medline

Yehuda R, McFarlane AC, Shalev AY (1998) Predicting the development of posttraumatic stress disorder from the acute response to a traumatic event. Biol Psychiatry 44:1305-1313. CrossRef Medline 